\title{
Young, Champollion, and Hieroglyphics
}

\section{By Dr. Allan Ferguson}

$\mathrm{I}^{\mathrm{T}}$ $\mathrm{T}$ is a seemly thing to " praise famous men ... renowned for their power, giving counsel by their understanding ... who were honoured in their generation, and were the glory of their times ", but it is well, even in a centenary notice, to be strictly accurate in assigning priority. Champollion accomplished great and lasting work for Egypto$\log y$, but it is not correct to describe him as the man "who first deciphered the hieroglyphics" (NAture, p. 307, Feb. 27, 1932). The phrase implies a rounded-off and complete contribution to knowledge such as is seldom made by any pioneer, and was certainly not made by Champollion. He did notable work in the deciphering of hieroglyphics, but he owed much to the labours of at least one of his predecessors, and unfortunately was not at all ready to acknowledge the help which such work had afforded him.

To-day it is not a question for discussion-it is a matter of fact that the first successful steps towards the solution of the problem of hieroglyphics were due to the genius of Thomas Young; and it is demonstrable that Champollion had not realised the correct mode of attack on the problem until Young's discoveries pointed out the way.

Young's is an arresting character-he crowded into his fifty-six years of life (1773-1829) more and more varied discoveries than seems possible for any one man, however greatly gifted. His work in optics, in the theory of surface forces, and in the science of Egyptology is in the first rank. Less important, but illustrating his amazing versatility, are his contributions to medical science and to the theory of the tides, his articles on subjects so diverse as life assurance, bridges, carpentry, and pendular oscillations. His gifts of scholarship are well exhibited in recorded notes of conversations with London scholars-notes which show that, at the age of eighteen, he could argue questions of criticism and emendation, on not unequal terms, with the great Porson himself.

The study of the development of genius is always interesting, and never more so than in the case of Young.* In spite of the immensity and variety of his learning, the amount of his reading was not very large, but "he adhered strictly through life to the principle of doing nothing by halves. Whatever book he had begun to read, he read completely and deliberately through; whatever study he commenced, he never abandoned; and it was by steadily adhering to this principle... that he was accustomed to attribute in after life a great part of his success, both as a scholar and as a man of science."

It is noteworthy that he took small account of any gifts of inspiration of genius, laying weight

* Peacock, "Life of Young", ; Leitch, "Young's Miscellaneous Works" (3 vols.); E. A. Wallis Budge, "First Steps in Egyptian" E. A. Wallis Budge, "The Decrees of Memphis and Canopus" (3 vols.). rather on concentration and on an accurate knowledge of, and attention to, matters of detail. This last-named power is shown in his exquisite Greek script - calligraphy in the literal sense of the termand its application as a weapon of research cannot be better exhibited than in his copies of the Rosetta stone inscriptions and in his laborious piecing together of their texts.

The story of the Rosetta stone has not been told so often as to have lost its interest, and in view of Champollion's centenary, may bear retelling.

It was in 1799 that the stone was unearthed by a French engineer engaged in digging the foundations of a fort in the neighbourhood of Rosetta, a small Egyptian town some miles north-east of Alexandria and situated on an arm of the Nile near its mouth. With many other antiquities it was handed over to the English after the capitulation of Alexandria, and was deposited in the British Museum in February 1802. It is a slab of black basalt 11 inches thick, and in surface dimensions is now about 3 feet 9 inches by 2 feet $4 \frac{1}{2}$ inches, but it has lost large fragments from the upper corners and from the right-hand bottom corner. In its unmutilated state it was probably 5 or 6 feet high. It carries three inscriptions, written in two languages. The uppermost inscription is written in the sacred character, the middle in the cursive demotic character, and both these inscriptions are in the Egyptian language. The third and lowermost inscription is written in the Greek language and in Greek uncial characters.

It follows from the manner in which the stone has been mutilated that the hieroglyphic text has suffered most. The demotic text contains 32 lines, 14 being imperfect at the beginnings; the Greek text contains 54 lines, 26 being mutilated at the ends ; the hieroglyphic text contains some 14 lines, about half of the text having disappeared.

In the year 196 B.c., there was a general assembly of Egyptian priests held at Memphis to commemorate the accession of Ptolemy V. By reason of the benefits that Ptolemy had conferred upon the land-benefits which included gifts to the temples, remission of taxes, the administration of justice, abolition of the press-gang for the navy, and the founding of temples-the priests assembled in council decreed that certain specified additional honours should be paid to him and to his ancestors ; and they further ordained that the decree should be inscribed upon "a stele of hard stone in the writing of the words of the gods, and the writing of books, and the writing of the lords of the North, and it shall be made to stand in the sanctuaries in the temples ... near the statue of the King of the North and South, Ptolemy, living for ever, beloved of Ptah, the God who maketh himself manifest, whose deeds are beautiful"

No. 3261, VoL. 129] 
This, then, is the import of the inscriptions on the famous stone.

Egyptian writing exists in three forms-hieroglyphic, the sacred picture-writing; hieratic, a simplified form of hieroglyphics; and demotic, an abbreviated form of hieratic writing. We have to remember, in order to realise fully the difficulties that faced the pioneers in this work, that a hieroglyphic symbol may be an ideograph, or may represent a sound, and in the latter case it may represent either a syllable or a letter. The difficulties of elucidation are further emphasised by the existence of determinatives, or signs which help to represent the meanings of words written with the aid of alphabetic or syllabic symbols. Thus, to take a very simple example, the word for obelisk (tekhen) may be written by drawing the picture of an obelisk ; if, however, we write the word by means of the alphabetic symbols $t, k h, n$, we make assurance doubly sure by following this by a picture of an obelisk, used as a determinative.

The Greek text was early deciphered, and a conjectural restoration of the ends of the mutilated lines was made by Porson. The Oriental scholars, Silvestre de Sacy and Akerblad, worked at the demotic text with some small measure of success, but the first seriously successful attack on the Egyptian inscriptions was made by Young. So early as 1814, Young had made translations of these texts, and in his "Account of some recent Discoveries in Hieroglyphical Literature and Egyptian Antiquities ", published in 1823 , he enumerates some nine of his early deductions - that simple objects are represented by their actual delineations, and that many signs are used in a figurative sense; he gives the signs for the dual and the plural, for units and for tens, the rule for the direction in which hieroglyphics must be read, remarks that the name of Ptolemy alone existed on the Rosetta stone, and that proper names are included in an oval ring.

This account of his early work was published in 1823 and, in a disputed question of priority, needs careful and critical comparison with the earlier dated publications; we have now, however, to chronicle the publication of a work which, without the slightest possibility of cavil, establishes Young's priority in this region of research. This is the article on "Egypt", originally published in 1819 in the supplement to the "Encyclopædia Britannica". In the plates which accompany this article he prints a word list, and, most important of all, gives a list of alphabetic and syllabic characters. Out of thirteen signs, six are correct, three partly correct, and four wrong. This article, as Sir E. A. Wallis Budge remarks, "is practically the foundation of the science of Egyptology, because it contains a list of a number of alphabetical Egyptian characters to which, in most cases, he had assigned correct value. In other words, the idea of a phonetic principle in the reading of hieroglyphics, which had been but dimly comprehended by Warburton, De Guignes, Barthélemy, and Zoega, was clearly grasped by Dr. Young, and was accurately applied by him FOR THE FIRST TIME in the history of the decipher- ment of the Egyptian hieroglyphic. As Chabas rightly expressed it, 'Cette idée fut, dans la réalité, le fiat lux de la science '."

Now let us briefly consider the claims of Champollion (1790-1832) to be described as the first decipherer of the hieroglyphics. Devoted as he was to classical and Oriental studies from an early age, he accumulated a mass of knowledge which, in this field, far surpassed that of Young. In 1812 he was appointed professor of ancient history at Grenoble, and in 1821 he published his treatise, "De l'écriture hiératique des anciens Égyptiens". In the course of this work he states unambiguously that hieratic writing is not alphabetic, that it is a simple modification of the hieroglyphic system, differing therefrom merely in the form of the signs, that it must be considered as hieroglyphic tachygraphy, and that hieratic characters are signs of things and not signs of sounds.

It is obvious, therefore, that despite Young's publication of 1819, Champollion, in 1821, was convinced that there was no trace of an alphabet in the hieroglyphic and hieratic characters. In 1822 all is changed. Champollion now publishes his famous " Lettre à $M$. Dacier, relative à l'alphabet des hiéroglyphes phonétiques employés par les Égyptiens pour inscrire sur leurs monuments les titres, les noms et les surnoms des souverains grecs et romains ", in which the alphabetic character of many of the symbols is clearly defined and an alphabet published. As we have seen, Young had already published an alphabet based on an analysis of the names Ptolemy and Berenice. Moreover, it should be noted that Bankes had identified as a whole the set of signs which make up the name of Cleopatra. With the letters obtained from Ptolemy and Berenice as a guide, it becomes a matter of cryptogram analysis to find the meaning of the unidentified symbols in the signature of Cleopatra, and with every further extension to a new name the process becomes more easy and more certain.

What is to be assigned as the cause of the remarkable change in the opinions of Champollion? Peacock states categorically that Champollion endeavoured to suppress his unfortunately expressed work of 1821 ; it is certain that he sent the illustrations of the work to Young without the letterpress - a method admirably adapted to obscure the date of publication - and it is difficult to give any reason, at all creditable to Champollion, for his persistent misstatements concerning the relation of Young's researches to his own.

The probability is that Champollion, who must, before 1821, have become acquainted with Young's Egypt article of 1819, had not appreciated its full significance, more especially as some of its results are stated by Young in a characteristically diffident fashion. If we assume that Champollion realised the full meaning of Young's great advance only after he had published his work of 1821, the matter seems tolerably clear.

However this may be, it is certain that Champollion's contributions to the elucidation of hieroglyphics, great as they were, and carried as they

No. 3261, VoL. 129] 
were to a point which Young could never hope to reach, were posterior to, and probably determined by, Young's fundamental contribution.

"In a lapidary inscription a man is not upon oath," said Johnson. That is very true; and the great mass of such inscriptions may be permitted an affectionate exaggeration of the qualities of the departed. But when we read on the tablet in- scribed to Young's memory in Westminster Abbey a eulogium of Young as one who "alike eminent in almost every department of human learning, patient of unintermitted labour, endowed with the faculty of intuitive perception . . . first penetrated the obscurity which had veiled for ages the Hieroglyphics of Egypt", we are reading no more than the literal and unadorned truth.

\section{Oil and Petrol from Coal*}

By Prof. C. H. Lander, C.B.E.

$\mathrm{A}^{\mathrm{LT}}$ LL fuels consist essentially of carbon and hydro. gen combined in different proportions. In oil, the proportion of hydrogen to carbon is higher than in coal ; further, oil contains less oxygen than coal. It is thus obvious that in order to turn coal into oil the proportions of carbon, hydrogen, and oxygen must be suitably readjusted. Various ways of doing this have suggested themselves to the scientific mind, but oil was first produced commercially from coal almost, as it were, accidentally, for it is one of the by-products in the manufacture of gas from coal.

Gas is made by the destructive distillation of coal, usually termed carbonisation. In this process, the coal is heated to a high temperature in closed retorts; the gas and condensable vapours which are driven off are collected, and from the resulting liquid products a certain quantity of oil can be prepared. In the course of these reactions there is a redistribution of the carbon and hydrogen atoms ; the coke, which is left behind in the retort, consists mainly of carbon, and has a lower proportion of hydrogen than the original coal, while the liquid and gaseous products have a higher proportion of hydrogen than the original coal.

If the carbonisation is carried out at a lower temperature, say at a dull red heat instead of the bright white heat associated with normal gasmaking processes, the yield of gas is less and the yields of coke and liquid products greater, while the latter are more nearly akin to natural petroleum. This process is usually known as low-temperature carbonisation.

Since light spirit is at the present time far more valuable than heavy oils, there have been introduced methods of again redistributing the molecules in the liquid products from the carbonisation of coal, so as to obtain higher yields of the lighter spirit. During this process, which is known as cracking, a residue, which has been deprived of hydrogen, appears as coke. Cracking is also widely applied to the heavier fractions obtained in the distillation of petrol from natural oils.

In obtaining petrol directly from the carbonisation of coal, low temperature carbonisation, cracking pushed to its limits, and the scrubbing of the gas to recover further small quantities of light spirit have not up to the present been able to raise

* From the Friday evening discourse at the Royal Institution delivered on Nov. 20, 1931.

No. 3261, VoL. 129] the total yield of motor spirit beyond 6-7 gallons per ton of raw coal. It must, however, not be forgotten that the primary object of carbonisation processes is the manufacture of coke and gas, and that light spirit, valuable as it may be per gallon, is still only a by-product.

The enormous importance of oil and petrol in modern civilisation has naturally focused attention on the possibilities of reshuffling the molecules in the coal in a way favourable to greater oil production; but, as I have already pointed out, coal, as compared with oil, is deficient in hydrogen. The possibility therefore suggests itself of adding extra

\begin{tabular}{|c|c|c|c|} 
CARBON & \multicolumn{3}{|c|}{$\mathrm{H}_{2} \mathrm{O}_{2} \mathrm{NH}_{3}$} \\
\hline 95 & 5 & 12 \\
\hline 93 & 7 & 5 & HEAVY OIL \\
\hline 91 & 9 & 3 & MIDDLE OIL \\
\hline 88 & 12 & PETROL \\
\hline
\end{tabular}

FIG. 1.

hydrogen to the coal substance in order to make up this deficiency, and then, by some means or other, inducing the molecules of the mixture to reshuffle themselves into oil molecules. This has actually been accomplished, and for this success due credit must be paid to the work of Dr. Friedrich Bergius, at Mannheim, who was the first to liquefy coal by direct hydrogenation.

Important and striking developments of the hydrogenation process as applied to coal have been made during the past six years, in Great Britain mainly by the Fuel Research Board and Imperial Chemical Industries, Ltd. Fig. $1 \dagger$ shows how the oxygen, nitrogen, and sulphur in the coal are removed as water, ammonia, and sulphuretted hydrogen. The residual hydrocarbons in the coal (95 per cent $\mathrm{C}, 5$ per cent $\mathrm{H}$ ) break down and combine with hydrogen to give a large percentage of petrol (88 per cent $\mathrm{C}, 12$ per cent $\mathrm{H}$ ), the solid material probably passing through heavy oil (93 per cent $\mathrm{C}$, 7 per cent $H$ ) and middle oil (91 per cent $C, 9$ per cent $\mathrm{H}$ ). It will be seen that although at present

+ For this and the other illustrations selected from the original discourse for publication here, thanks are due to Imperial Chemical Industries, Ltd. 